\title{
JUURNAL_RU
}

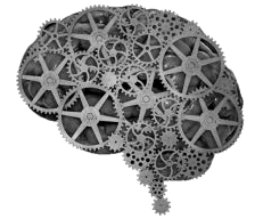

COMPANY GROUP "INTELLEKT"

\author{
Яковлева С.П., Махарова С.Н., Васильева М.И. \\ Институт физико-технических проблем Севера СО РАН \\ Якутск, Россия
}

doi: 10.18411/lj2016-5-4-13

\section{Влияние термической обработки на поверхность износа алмазометаллических композитов}

Процесс изнашивания алмазосодержащего инструмента объединяет следующие факторы: изнашивание алмазных зерен и изнашивание матрицы. При этом изнашивание алмазных зерен имеет такие характерные формы, как затупление, скалывание или вырыв. Механизм изнашивания матрицы обычно носит абразивный характер: истирается твердыми частицами камня или выпавшими алмазными зернами.

В ИФТПС им. В.П. Ларионова СО РАН разработана технология получения износостойких алмазометаллических композитов (АМК) при ударно-волновом прессовании с последующей термообработкой смесей порошков природного алмаза и дешевых порошков сплавов на основе железа [1]. Научные основы технологии базируются на следующих факторах: интенсивное упрочнение компонент металлической матрицы при термообработке после ударно-волнового формования; возможность обеспечения лучшей сохранности алмазной компоненты; высокое алмазоудержание.

Распределение алмазных частиц на поверхности АМК после взрывного прессования (ВП) равномерное, но закрепление их в матрице, по-видимому, преимущественно механическое, о чем свидетельствует частичное выкрашивание алмазов при подготовке шлифа. В работе [2] показана возможность повышения ударной вязкости обработанного взрывом материала 
путем кратковременного нагрева. Это связано с особенностью эволюции карбидной фазы при нагреве деформированного взрывом материала. Также следует ожидать, что при нагреве вследствие взаимодействия углерода алмаза с материалом матрицы механическая связь между ними будет дополнена более прочной химической.

Исходя из вышеизложенного, проведена термическая обработка прессовок по следующим трем режимам: I - нагрев до 800o C, II - нагрев до 900о C, III нагрев до 1000о С (время выдержки во всех случаях 15 мин.), средние значения микротвердости 1870,2440 и 3210 МПа соответственно. Структурные исследования прессовок после термической обработки показывают, что при 800оС заметной диффузии углерода нет, по границам исходных зерен наблюдаются прослойки оксидов и снижение микротвердости. Повышение температуры отжига до 900 o C увеличивает количество перлитной составляющей и значения микротвердости. Продолжается восстановление оксидов. Значительное увеличение микротвердости при термообработке по режиму III связано с появлением участков с заэвтектоидным составом. Следует отметить улучшение алмазоудержания после проведенной термообработки: выкрашивание алмазов при подготовке шлифов практически не наблюдается.

О степени алмазоудержания в АМК можно судить по характеристикам износа, так как износостойкость определяется наличием алмазных частиц, а их удаление с поверхности трения приводит к быстрому изнашиванию матрицы.

Результаты испытаний АМК на износостойкость при трении о закрепленные абразивные частицы, показывают, что термическая обработка явилась эффективным средством повышения алмазоудержания алмазометаллического материала (линейный износ $\Delta \mathrm{h}$ уменьшается приблизительно в 4 раза).

Исследованы поверхности износа для выявления причин изменения износостойкости в зависимости от режима термообработки. Удаление зерен алмаза в исходном состоянии прессовок (сразу после ВП) происходит по двум 
механизмам: вырывом (рис.1,a) и отколами (рис.1,б). После отжига по первому режиму и снижения твердости матрицы превалирует механизм вырыва алмазных частиц, чем объясняется увеличение износа материала. При повышении температуры отжига до 900оС происходит рост сопротивления износу вследствие улучшения алмазоудержания. Фрактографически это подтверждается преимущественно транскристаллитным механизмом разрушения алмазных зерен (рис.1,в).

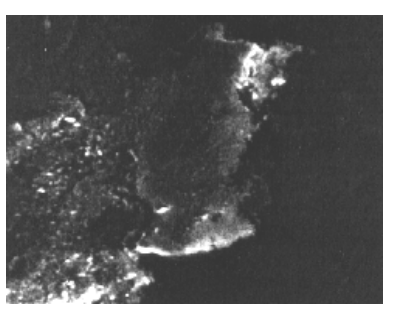

a

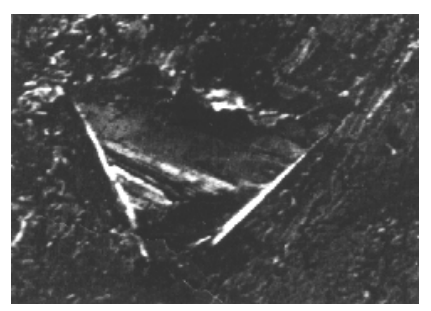

6

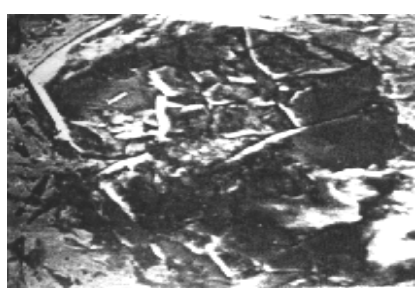

B

Рис.1. Поверхность износа алмазометаллического композита в состоянии после взрывного прессования (а - х900; б - х1000) и после термообработки при 900оС (в - х 800).

Картины разрушения алмазной составляющей в прессовке, отожженной при $10000 \mathrm{C}$, аналогичны показанной на рис.1,в. Несмотря на значительное увеличение микротвердости, уровень износа соответствует значениям, полученным для предыдущего режима. По-видимому, это обусловлено изменением прочности алмазов, подвергнутых воздействию высокой температуры, а также возможным охрупчиванием матрицы при повышенном содержании углерода.

Таким образом, термообработкой при 900 0С и 1000 0С достигается достаточно прочное закрепление алмазных частиц в матрице. Изменяется механизм разрушения и удаления алмазных зерен с поверхности износа АМК. 


\section{Литература:}

1. Ларионов В.П., Яковлева С.П., Махарова С.Н., Винокуров Г.Г., Васильева М.И. Разработка научных основ технологии получения алмазометаллических композитов взрывным прессованием / Химическая технология. - 2002. - №1. - С. 28-32.

2. Гаврильев И.Н., Соболенко Т.М., Яковлева С.П. Влияние взрывного нагружения на микропроцессы разрушения конструкционных сталей // Металловед. и термич. обр. металлов. - 1986. - №12. - С.20-22. 